\title{
A Customer-focused Approach to Distribution: The Case OF SANPARKS
}

\author{
Anneli Douglas \\ Department of Tourism Management, University of Pretoria \\ Accepted: March 2016
}

\begin{abstract}
While the importance of distribution has been recognised in tourism literature, the research has been approached mainly from the perspective of supply, with very little attention given to the customer. To date, there has been even less focus on the distribution channel requirements of the National Park customers. The purpose of this study is to examine how the various distribution channels used by South African National Parks (SANParks) go towards satisfying the customers' distribution channel requirements and identifying whether there is any relationship between certain variables, such as gender or the frequency of channel use, and the level of satisfaction that customers experience with the various channels. Web-based and paper-based questionnaires are distributed to the customers who have used the SANParks distribution channels before. The results show that, although the SANParks website is the most frequently used channel for making a booking, it is not necessarily the channel with which customers are most satisfied; in fact, they are more satisfied with the satellite walk-in reservation offices and satellite call centres. While the majority of the research studies in the context of tourism distribution channels have shown the importance and popularity of electronic distribution channels among customers, this paper cautions SANParks not to assume the distribution channel requirements of their customers and urges them to continually assess their distribution strategies and to become more customer-focused in their approach.
\end{abstract}

Key words: channel requirements, customer-focused, distribution channels, SANParks, satisfaction, supplier

JEL: L83

\section{$1 \quad$ Introduction}

Distribution adds to the competitiveness of tourism businesses and affects other elements of the marketing mix, for example, price, product and promotion (Pearce, 2002), while, at the same time, influencing the profitability of the tourism value chain members (Buhalis, 2000; Coelho \& Easingwood, 2008). Buhalis (2001:8) defines the primary distribution functions for tourism as: "information, combination and travel arrangement services. Most distribution channels therefore provide information to prospective tourists; bundle tourism products together; and also establish mechanisms that enable consumers to make, confirm and pay for reservations". Middleton and Clarke (2001) add that the core distribution functions are to extend the number of points of sale or access away from the location at which services are performed or delivered and to enable the purchase of products before their production.

Even though researchers are increasingly focusing their attention on tourism distribution, literature on the topic continues to reveal numerous gaps (Schott, 2007). Pearce and Schott (2005) and Schott (2007) note that the focus of distribution studies has been mainly on supply-side issues, such as the relationship between suppliers and intermediaries (for example, travel agents, inbound and outbound tour operators, and tour wholesalers), and their efforts to reach customers (O’Connor, 1999; Buhalis, 2001; Alcázar Martínez, 2002; Crotts, Aziz \& Raschid, 1998; GarcíaFalcón \& Medina-Muñoz, 1999). Far less attention has focused on customers and how they perceive and use the various channels of distribution (Öörni, 2003; Wolfe, Hsu \& Kang, 2004), even though many authors have identified the need for distribution research to be more customerfocused. Buckley (1987) became convinced of the importance of the customer when he adopted the transaction chain analysis and asserted that an analysis of transactions should start with the 
"main actor" - the tourist- and it should study all the "actor's" transactions (Pearce \& Schott, 2005:50). Pearce and Schott (2005) emphasise that research investigating the channels suppliers use should be supplemented by related studies from the demand side (Lituchy \& Rail, 2000). Pearce (2009) urges suppliers to be customer-focused by taking the customers' distribution requirements into consideration, while Pearce and Schott (2005) identify the need to extend research on consumer behaviour in tourism past the information search process to include a more comprehensive study on booking and buying behaviour. This is so that a more thorough understanding of the process of distribution from the customer's perspective can be gained. When visitor behaviour and use is better understood, it will allow suppliers to serve their customers more successfully, by either confirming their current distribution strategies or recommending ways of improving these. This should lead to a more effective distribution of products in a marketplace that is becoming more competitive.

In order to gain a better understanding of the distribution process from the customers' perspective, the focus of this study will be on examining their use of SANParks' various distribution channels. More specifically, the study aims to: assess the frequency with which the customers use the SANParks' distribution channels; measure the extent to which the customers' distribution requirements are being satisfied and identify whether there is a relationship between certain variables, such as gender or frequency of travel, and the level of satisfaction with the various channels experienced by the customers. SANParks is known to be the leading conservation agency in South Africa (Saayman \& Saayman, 2008), and is responsible for 22 national parks, covering 3751113 hectares of protected land (SANParks, 2013). SANParks conserves the fauna, flora and landscapes indigenous to South Africa and is closely associated with the cultural heritage and history of the country. The Parks offer various accommodation facilities and activities that cater for visitors' different needs and wishes (SANParks, 2013).

SANParks was selected as a case study for the following reasons: first, research into the area of tourism distribution in the national parks is almost non-existent. Sharpley and Pearce (2007) explored marketing and marketing perspectives in encouraging sustainable tourism in national parks in England, while Tsai, Chou and Lai (2010) analysed the websites of national parks in Taiwan, but, to date, no studies have investigated the use and requirements of the various distribution channels in the context of national parks. Second, when taking the visitor demographics of SANParks into consideration, it is evident that the majority of visitors represent an older demographic (Scholtz, du Plessis \& Saayman, 2014). It should be noted that, even though the age profile presented by Scholtz et al. (2014) was drawn from overnight visitors to the Southern part of the Kruger National Park, this still provides an indication of the general age profile of visitors to SANParks. Research shows that the popularity of electronic distribution channels is increasing (TravelCLICK in Inversini \& Masiero, 2014), but older generations prefer more traditional channels (Beldona, Racherla \& Mundhra, 2011). The question therefore arises as to whether the SANParks' older visitors demographic prefer to use electronic channels or more traditional distribution channels.

The remainder of the paper is structured as follows: first there is a review of the extant literature relevant to the distribution of tourism services from the demand perspective approach and then the research methodology is presented. Finally, the results are discussed and summarised.

\section{Tourism distribution channels}

Stern and El-Ansary (1992) view distribution channels as a coordinated system that must produce value for the user or consumer through the creation of form, possession, time and place functions. Arranging this system can be a "balancing act" when considering the variety of channel members who are all interdependent, which involves numerous functions (Pearce, 2009). Compromise and cooperation are needed to line up the supplier's resources with what is needed to gratify the consumer and stay abreast of its opponents (Anderson, Day \& Rangan, 1997). Pearce (2009) confirms that the design process must be customer-focused and must take the distribution 
requirements of customers into account, while at the same time considering the business's own requirements. This would result in the best possible match between these two sets of requirements.

Morrison (1989) describes the distribution mix in tourism as the combination of the direct and indirect distribution channels used by tourism organisations, whereby direct distribution takes place when the organisation accepts complete responsibility for promoting, making reservations and providing services to customers. On the other hand, there is indirect distribution when part or all of the responsibility for these functions lies with a third party, typically a travel trade intermediary. In an effort to sell their services more efficiently, most suppliers use a mix of traditional and electronic channels (Morosana \& Jeong, 2008). Bennett and Lai (2005) as well as Law, Leung and Wong (2004) state that traditional and electronic distribution channels can complement each other to deliver the ultimate satisfaction for travellers (Huang, Chen \& $\mathrm{Wu}$, 2009).

SANParks uses both traditional and electronic distribution channels, that is, a supplier website, a head office reservation office, a call centre, a number of satellite reservation offices and satellite call centres (as depicted in Figure 1). These channels, their functions and their use by customers will be discussed.

Figure 1

SANParks' distribution system

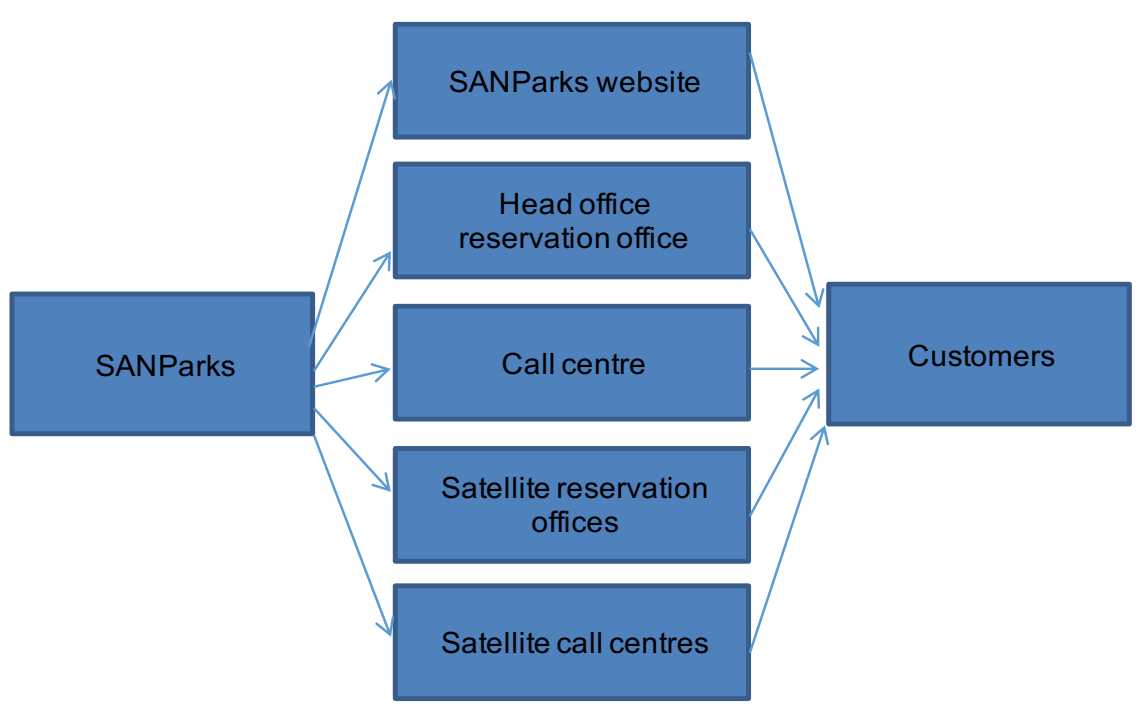

\section{Reservation offices (Retail travel agents)}

SANParks distributes their accommodation offering by means of a head office reservation office together with a number of satellite reservation offices situated across South Africa. These offices act as reservation agents, and the reasons customers would make use of them would be similar to the reasons for which they would choose a retail travel agent. Some researchers (Palmer \& McCole, 1999; Pan, MacLaurin, \& Crotts, 2007; Tsai, Huang \& Lin, 2005) maintain that, even though the number of online travel transactions is increasing, travellers still depend on travel agents to offer a human touch and a professional service. Walle (1996) thinks that a core advantage of travel agencies is their ability to deliver personalised information and assistance to travellers on an on-going basis by answering questions, handling problems and preserving a relationship with clients (Cheyne, Downes \& Legg, 2006). Law, Leung and Wong (2004) maintain that the role of travel agencies is secure if their ability to give advice is supported by the Internet, instead of simply functioning according to the more negative image of being only a "booking agency". Cheyne et al. (2006) agree, adding that the travel agent must be more than a mere 
reservation office for tickets. They should deliver more added value with the information and guidance they give clients. More recently, Lu, Yang and Yuksel (2015) examined two competitive advantages of intermediaries like retail travel agents, namely information competitive advantage, which relates to the ability to obtain, offer and use information (whether product information or information on the consumer) and value-adding competitive advantage, referring to an intermediary's ability to offer consumers value-added services and products. Kim, Lehto and Morrison (2007) argue that more multifaceted travel products will continue to be distributed through traditional distribution channels.

According to $\mathrm{Lu}$ et al. (2015), the implementation of a direct electronic channel by suppliers has increased the conflict between suppliers and their intermediaries and has encouraged a discussion on the probable disintermediation of intermediaries (Buhalis \& Licata, 2002; Giaglis, Klein \& O'Keefe, 2002; Sen \& King, 2003). A number of studies conducted in the tourism environment, have examined the influence of direct electronic channels on travel agencies and have debated different approaches whereby travel agencies could stay relevant in the future (Dolnicar \& Laesser, 2007; Law, 2009; Novak \& Schwabe, 2009; Suarez Alvarez, Diaz Martin \& Casielles, 2007). Law (2009) looks at the perceptions by travellers of travel agency disintermediation and proposes that the Internet cannot substitute travel agents completely and that travel agents still have a role to play. Suarez Alvarez et al. (2007) advise retail travel agencies to increase their competitiveness by having online presence, as consumers perceive the travel agency's online channel to be a value-added service. Dolnicar and Laesser (2007) maintain that travel agents should focus on specific travel contexts in which they have competitive advantages, like package holidays, transport services, beach or city holidays and lesser-known destinations. Considering the rapid changes in the business and the technological context, earlier research results may not precisely mirror the present situation, as industry practitioners are expected to see and respond differently to disintermediation. What is more, subsequent research effort has been largely lacking over the past few years (Law, Leung, Lo, Leung, Hoc \& Fong, 2015). In 2010, one study investigated practitioners' viewpoints regarding disintermediation in tourism and hospitality. (Kaewkitipong, 2010). Thakran and Verma (2013) are of the opinion that the reason for the current distribution context moving towards disintermediation is the result of suppliers being keen to distribute their products and services via new online technologies like social media and mobile devices.

\section{Call centres}

Those customers preferring the traditional way of doing things still find the conventional telephone a popular channel to use (Buhalis \& Licata, 2002). For this reason, SANParks still facilitates the distribution of their services through a call centre and satellite call centres. According to Pearce, Tan and Schott (2007), call centres provide a "concentration of expertise", which increases sales opportunities by extracting more out of clients when dealing directly with them, through up-selling and cross-selling. Even though consumers' confidence in online booking is increasing, they may prefer to confirm their reservations or put questions to a call centre agent. Call centres, in fact, support a supplier's Internet distribution (Buhalis \& Licata, 2002).

\section{SANParks website}

SANParks also makes use of its own website to distribute its offering. There has been a significant growth in the number of direct bookings on supplier websites (Phelan, Christodoulidou, Countryman \& Kistner, 2011). Starkov and Safer (2010) maintain that the supplier website should be the focus of any distribution strategy, as consumers who book on the supplier website are more loyal, spend more and are likely to travel more frequently. The internet allows consumers to have access to trustworthy and correct information, in addition to having the opportunity of completing bookings quicker and cheaper, with fewer problems, in comparison with traditional methods (Crnojevac, Gugić \& Karlovčan, 2010). Supplier website users can be placed in two categories, namely browsers (lookers) and buyers (bookers) (Law \& Hsu, 2006). Even though the internet is 
used as an important tool when searching for information and buying products, consumers still use diverse distribution channels when making decisions. Although some consumers may look for information online, they may still end up buying offline (Crnojevac et al., 2010). According to Bai, Law and Wen (2008), website quality has a direct and positive effect on customers' satisfaction as well as on their commitment to buying online, making it imperative for suppliers to satisfy their customers if they are to be e-buyers and not only e-searchers (Crnojevac et al., 2010).

From the above discussion, it becomes clear that different distribution channels appeal to different customers. In order for suppliers to serve their customers more successfully, they need to understand their distribution requirements. What will ultimately lead to the successful use of a specific channel by customers is whether the supplier will manage to satisfy the consumers' distribution requirements with the particular channel. Customers' satisfaction with a channel will ultimately depend on how they measure the performance of the channel. According to Pearce and Taniguchi (2008), the development of an efficient distribution system in a market that is becoming more and more competitive asks for both a careful evaluation of the performance of specific channels and the whole distribution mix. They further note that other authors, such as Kotler, Bowen and Makens (1996); Anderson et al. (1997); Middleton and Clarke (2001) and Green (2005), have also emphasised the need to assess the performance by specific channels. However, very little direction has been given on how such an evaluation should be conducted.

In the airline industry, for example, the development of online direct sales systems has enticed a lot of interest and has apparently been built on thorough assessments of channel benefits and disadvantages. Nevertheless, these studies seem to relate to the outcomes of the development of distribution channels and not to the methods by which channel assessments have been conducted (Lubbe, 2005; Alamdari \& Mason, 2006). More recently, Kontis and Lagos (2015) have reiterated the need for assessing and evaluating distribution channels, and point out that the current theoretical frameworks are limited when it comes to undertaking such assessments. They looked at scientific research studies that have attempted to evaluate tourism distribution channels, but find that these studies either focus on the one-sided link between income/expenses per channel used (Sanchez \& Ahmet, 2005) or on assessing the performance of the tourism supply chain (Yilmaz \& Bititci, 2006). They conclude that the lack of a scientifically documented functional and efficient set of evaluation factors of the performance by different distribution channels in the accommodation sector prevents marketing decision-makers from obtaining the critical proof essential to the development of applicable selling and distribution strategies of their product (Kontis \& Lagos, 2015). The next section will thus focus on channel performance and the measurement thereof.

\section{Channel performance from the customer's perspective}

Pearce (2008) notes that when visitor behaviour and use are better understood, it will allow suppliers to serve their customers more successfully, leading to a more effective distribution of their products in a marketplace that is becoming more competitive. Crnojevac et al. (2010) think that when suppliers want to increase the quality of their online service, they should constantly adjust their online marketing strategy to the requirements of the customers, centred on measurements of customer satisfaction and experience and on features of customer behaviour. Even though this statement was made in the context of electronic distribution, the same rings true for traditional distribution.

Customers measure the performance of distribution channels according to the channel's ability to satisfy their distribution requirements. The available literature identifies the requirements that are important to customers when measuring the performance by the distribution channels used by SANParks. Table 1 indicates these requirements as well as the item in the questionnaire (to be used in the empirical section of this study) that corresponds with the customer requirement. 
Table 1

Customer requirements used when measuring the performance of distribution channels

\begin{tabular}{|c|c|c|c|c|c|}
\hline Travel agent & $\begin{array}{l}\text { Corresponding } \\
\text { item in } \\
\text { questionnaire }\end{array}$ & Call centre & $\begin{array}{l}\text { Corresponding item } \\
\text { in questionnaire }\end{array}$ & Supplier website & $\begin{array}{l}\text { Corresponding } \\
\text { item in } \\
\text { questionnaire }\end{array}$ \\
\hline $\begin{array}{l}\text { Security of payment } \\
\text { process } \\
\text { (Cheyne et al., } \\
\text { 2006) }\end{array}$ & $\begin{array}{l}\text { Security of payment } \\
\text { process }\end{array}$ & $\begin{array}{l}\text { Lack of queues } \\
\text { (Dean, 2004) }\end{array}$ & $\begin{array}{l}\text { Time taken to } \\
\text { answer your call (call } \\
\text { centre); Time taken } \\
\text { to make the } \\
\text { reservation (website) }\end{array}$ & $\begin{array}{l}\text { Perceived price } \\
\text { (Golmohammadi, } \\
\text { Jahandideh \& } \\
\text { O'Gorman, 2012) }\end{array}$ & $\begin{array}{l}\text { Price of } \\
\text { accommodation } \\
\text { charged }\end{array}$ \\
\hline $\begin{array}{l}\text { Reliability } \\
\text { (Cheyne et al., } \\
\text { 2006) }\end{array}$ & $\begin{array}{l}\text { Reputation } \\
\text { (credibility of } \\
\text { reservation channel) }\end{array}$ & $\begin{array}{l}\text { Friendly manner } \\
\text { (Dean, 2004) }\end{array}$ & $\begin{array}{l}\text { Overall } \\
\text { professionalism }\end{array}$ & $\begin{array}{l}\text { Perceived risk } \\
\text { (Golmohammadi, } \\
\text { Jahandideh \& } \\
\text { O'Gorman, 2012) }\end{array}$ & $\begin{array}{l}\text { Reputation } \\
\text { (credibility of } \\
\text { reservation } \\
\text { channel) }\end{array}$ \\
\hline $\begin{array}{l}\text { Assurance } \\
\text { (Cheyne et al., } \\
\text { 2006) }\end{array}$ & $\begin{array}{l}\text { Reputation } \\
\text { (credibility of } \\
\text { reservation channel) }\end{array}$ & $\begin{array}{l}\text { Provision of } \\
\text { information } \\
\text { (Jaiswal, 2008) }\end{array}$ & $\begin{array}{l}\text { Knowledge of } \\
\text { reservation staff }\end{array}$ & $\begin{array}{l}\text { Convenience } \\
\text { (Jun, Vogt \& } \\
\text { Mackay, 2010) }\end{array}$ & $\begin{array}{l}\text { Ease of payment } \\
\text { process }\end{array}$ \\
\hline $\begin{array}{l}\text { Someone to contact } \\
\text { when things go } \\
\text { wrong } \\
\text { (Cheyne et al., } \\
\text { 2006) }\end{array}$ & $\begin{array}{l}\text { Personal contact } \\
\text { provided by } \\
\text { reservation staff }\end{array}$ & $\begin{array}{l}\text { Quality of } \\
\text { information } \\
\text { (Jaiswal, 2008) }\end{array}$ & $\begin{array}{l}\text { Knowledge of } \\
\text { reservation staff }\end{array}$ & $\begin{array}{l}\text { Timely availability } \\
\text { of information } \\
\text { (Jun, Vogt \& } \\
\text { Mackay, 2010; } \\
\text { Sabiote, Frías \& } \\
\text { Castañeda, 2012) }\end{array}$ & $\begin{array}{l}\text { Availability of } \\
\text { accommodation }\end{array}$ \\
\hline $\begin{array}{l}\text { Individualised } \\
\text { service } \\
\text { (Cheyne et al., } \\
\text { 2006) }\end{array}$ & $\begin{array}{l}\text { Personal contact } \\
\text { provided by } \\
\text { reservation staff }\end{array}$ & $\begin{array}{l}\text { Relational } \\
\text { expertise } \\
\text { (Burgers, Ruyter, } \\
\text { Keen \& Streukens, } \\
\text { 2000) }\end{array}$ & $\begin{array}{l}\text { Personal contact } \\
\text { provided by } \\
\text { reservation staff }\end{array}$ & $\begin{array}{l}\text { Trust } \\
\text { (Jun, Vogt \& } \\
\text { Mackay, 2010) }\end{array}$ & $\begin{array}{l}\text { Reputation } \\
\text { (credibility of } \\
\text { reservation } \\
\text { channel) }\end{array}$ \\
\hline $\begin{array}{l}\text { Relationship } \\
\text { (Novak \& Schwabe, } \\
2009\end{array}$ & $\begin{array}{l}\text { Personal contact } \\
\text { provided by } \\
\text { reservation staff }\end{array}$ & $\begin{array}{l}\text { Responsiveness } \\
\text { (Keiningham, } \\
\text { Aksoy, Andreassen, } \\
\text { Cooil \& Wahren, } \\
\text { 2006) }\end{array}$ & $\begin{array}{l}\text { Ease of booking } \\
\text { (hassle free) }\end{array}$ & $\begin{array}{l}\text { Ease of use } \\
\text { (Kim \& Lee, 2004; } \\
\text { Sabiote, Frias \& } \\
\text { Castañeda, 2012) }\end{array}$ & $\begin{array}{l}\text { Simplicity of self- } \\
\text { help process }\end{array}$ \\
\hline $\begin{array}{l}\text { Provide advisory } \\
\text { services } \\
\text { (Novak \& Schwabe, } \\
2009\end{array}$ & $\begin{array}{l}\text { Knowledge of } \\
\text { reservation staff }\end{array}$ & $\begin{array}{l}\text { Empathy } \\
\text { (Keiningham, } \\
\text { Aksoy, Andreassen, } \\
\text { Cooil \& Wahren, } \\
\text { 2006) }\end{array}$ & $\begin{array}{l}\text { Overall } \\
\text { professionalism }\end{array}$ & $\begin{array}{l}\text { Information content } \\
\text { (Kim \& Lee, 2004; } \\
\text { Sabiote, Frías \& } \\
\text { Castañeda, 2012) }\end{array}$ & Find information \\
\hline $\begin{array}{l}\text { Overcome } \\
\text { uncertainty } \\
\text { (Pavlou, 2003) }\end{array}$ & $\begin{array}{l}\text { Reputation } \\
\text { (credibility of } \\
\text { reservation channel) }\end{array}$ & $\begin{array}{l}\text { Reliability } \\
\text { (Keiningham, } \\
\text { Aksoy, Andreassen, } \\
\text { Cooil \& Wahren, } \\
\text { 2006) }\end{array}$ & $\begin{array}{l}\text { Reputation } \\
\text { (credibility of } \\
\text { reservation channel) }\end{array}$ & $\begin{array}{l}\text { Security } \\
\text { (Kim \& Lee, 2004; } \\
\text { Sabiote, Frías \& } \\
\text { Castañeda, 2012) }\end{array}$ & $\begin{array}{l}\text { Security of } \\
\text { payment process }\end{array}$ \\
\hline $\begin{array}{l}\text { Trust } \\
\text { (Izquierdo-Yusta \& } \\
\text { Marti'nez-Ruiz, } \\
\text { 2011) }\end{array}$ & $\begin{array}{l}\text { Reputation } \\
\text { (credibility of } \\
\text { reservation channel) }\end{array}$ & $\begin{array}{l}\text { Assurance } \\
\text { (Keiningham, } \\
\text { Aksoy, Andreassen, } \\
\text { Cooil \& Wahren, } \\
\text { 2006) }\end{array}$ & $\begin{array}{l}\text { Security of payment } \\
\text { process }\end{array}$ & $\begin{array}{l}\text { Personalisation } \\
\text { (Kim \& Lee, 2004) } \\
\text { Website design } \\
\text { (Musante, Bojanic } \\
\text { \& Zhang, 2009) } \\
\end{array}$ & $\begin{array}{l}\text { Recognition of } \\
\text { your personal } \\
\text { details }\end{array}$ \\
\hline $\begin{array}{l}\text { Local knowledge } \\
\text { (Cheyne et al., } \\
\text { 2006) }\end{array}$ & $\begin{array}{l}\text { Knowledge of } \\
\text { reservation staff }\end{array}$ & & & $\begin{array}{l}\text { Navigation } \\
\text { (Kim, Chung \& Lee, } \\
\text { 2011) }\end{array}$ & $\begin{array}{l}\text { Ease of finding } \\
\text { the SANParks } \\
\text { online booking } \\
\text { facility }\end{array}$ \\
\hline $\begin{array}{l}\text { Saving time } \\
\text { (Cheyne et al., } \\
\text { 2006) }\end{array}$ & $\begin{array}{l}\text { Time taken to make } \\
\text { the reservation; } \\
\text { Waiting time in } \\
\text { queue }\end{array}$ & & & & \\
\hline
\end{tabular}

It should be noted that certain variables might influence the way in which customers view some of the channel requirements, as shown in Table 1. These variables could include culture, gender, age, income level, regional differences, the level of skill in using the internet and the frequency of travel, to name but a few. Even though studies have investigated the relationship between these variables and the choice (or use) of preferred distribution channels (De Jager, 2014; Law, et al., 2015), very few have looked at these variables and how they influence customers' view of some of the channel requirements. Sabiote et al. (2012) noticed that cultural dimensions influence the 
relationship between the customers' channel requirements and the performance by the channel. In addition, Kim and Kim (2004) identified a relationship between the customer's skill in using the internet, and their channel requirements. Akhter (2003) and Powell \& Ansic (1997), for example, found that men and women are significantly diverse when it comes to the way in which they view the usefulness and user-friendliness of the internet. In comparison to women, men are generally less opposed to risk and more at ease with technology, and are open to online purchases. According to Izquierdo-Yustathe and Martínez-Ruiz (2011), men use the internet more as a channel, while women make greater use of the travel agency. Lubbe (2007) found differences between men and women, with men less anxious about making use of the internet for information, for general purchases and for travel purchases. Beldona et al. (2011) also found that the frequency of travel influences the way in which travellers measure the performance of a distribution channel. For example, the perceived risk of using a channel might affect the way in which the overall performance of the channel is measured. In other words, the more frequently someone travels, the lower they assess the risk of using a specific channel. Weber and Roehl (1999) found that the perceived risk of the product and the channel seems to be less for frequent travellers. The frequency with which a distribution channel is being used might also influence the performance measurement of the channel. According to Michopoulou and Buhalis (2008), the success of a website seems to be dependent on three variables; frequency of use, likelihood of return and user satisfaction. Contrary to this, Ryan and Cliff (1997) found no evidence that the frequency with which a travel agent is being used influences the level of satisfaction experienced with the travel agent. One of the objectives of the study is to see whether these variables, such as gender and frequency of travel, also play a role in the performance of SANParks' distribution channels as measured by their customers.

The above discussion scrutinised the functions of various distribution channels from the customer's perspective and identified the requirements customers specify when measuring their level of satisfaction with distribution channels. In order to gain a better understanding of the distribution process from the customer's perspective, the focus of this study is on examining customers' use of the various distribution channels of SANParks.

\section{Methodology}

Previous visitors to SANParks who had made use of SANParks distribution channels were selected as the population. To the best of the author's knowledge, no existing measurement instrument exists for assessing the performance by various distribution channels as judged by the customer, and so a new instrument had to be developed from literature. Table 1 contains an overview of the constructs from literature and the corresponding items in the questionnaire used to measure the construct. Convenience sampling was used and the link to the web-based questionnaire posted on the SANParks website, accompanied by an invitation to participate in the research. In total, 418 usable responses were gathered from the online survey. Paper-based questionnaires were also distributed at the head office walk-in reservation office, as well as a satellite walk-in reservation office, where 121 paper-based questionnaires were collected, which resulted in a total number of 539 responses. The purpose of the questionnaire was to examine how the various distribution channels used by SANParks perform in satisfying customers' distribution channel requirements and to identify whether there is a relationship (or a difference) between certain variables (such as gender, the level of skill in using the internet, frequency of travel and culture) and the level of satisfaction that customers experience with the various channels.

In this paper, the results of five channels of distribution covered in the questionnaire will be discussed: walk-in reservation offices (both head office and satellite), call centres (both head office and satellite) and the supplier website. SANParks' own walk-in reservation office is situated at their head office in Groenkloof, Pretoria. They also have a number of satellite walk-in reservation offices across South Africa. These satellite offices are independently owned and act as reservation agents for SANParks while earning a commission from SANParks on the reservations they make. 
SANParks also operate their own call centre. If the volume of calls is too large to handle in the call centre, they are transferred to satellite call centres, who once again earn a commission on the reservations they make for SANParks, and are independently owned.

Data were analysed using descriptive frequency analysis and measures of central tendency and dispersion to determine visitors' use of and experience with these channels. Further, inferential statistical analysis, namely independent sample t-tests, analyses of variance (ANOVAs) and Chisquare tests were conducted to investigate differences and relationships between variables, of which only those that proved to be significant are reported in this paper.

\section{Results}

A description of the respondents' profile is presented in Table 2. An equal number of males and females responded to the questionnaire. All the adult age groups were represented in the sample, and almost all the respondents visit one of the SANParks at least once a year.

Table 2

Respondents' profile

\begin{tabular}{|c|c|}
\hline Demographic profile & Percentage \\
\hline \multicolumn{2}{|l|}{ Age } \\
\hline $18-35$ & 17.17 \\
\hline $36-50$ & 31.11 \\
\hline $51-60$ & 24.68 \\
\hline Over 60 & 27.04 \\
\hline \multicolumn{2}{|l|}{ Gender } \\
\hline Male & 50 \\
\hline Female & 50 \\
\hline \multicolumn{2}{|l|}{ Frequency of visits } \\
\hline More than once a year & 65.34 \\
\hline Once a year & 30.46 \\
\hline I haven't stayed at any of the SANParks in the last two years & 3.57 \\
\hline I haven't stayed at any of the SANParks in the last five years & 0.63 \\
\hline
\end{tabular}

Customers' use of the various SANParks distribution channels

The respondents were asked to indicate how often they use the various SANParks distribution channels. From Table 3, it is clear that the website was used most frequently to make a reservation, followed by the call centres. In addition to being asked how often respondents used the SANParks website, they were also asked to show the frequency with which they conduct other activities on the website, such as checking the availability of accommodation and finding information. It seems that the most frequently-performed activity on the website is to check the availability of accommodation, followed by finding information. It is interesting that almost twice as many respondents indicated that they always used the website to check the availability of accommodation, as opposed to those always making reservations on the website. The respondents were then asked to give their reasons for not making reservations on the website (see Table 4 below). The most frequently-quoted reasons were: "I prefer to use other booking channels" (mentioned 78 times); "I don't like paying over the internet" (mentioned 54 times); "Pensioners do not receive discounts when booking on the SANParks website" (mentioned 49 times); "I don't like providing my personal details over the intern" (mentioned 45 times) and "The SANParks website only allows me to make a booking 10 months in advance, but with the other channels I can book 11 months in advance (mentioned 37 times)". 
Table 3

Frequency percentage with which SANParks distribution channels are being used and activities conducted on the SANParks website

\begin{tabular}{|c|c|c|c|c|c|}
\hline Channel & Always & Most of the time & Sometimes & Rarely & Never \\
\hline Call centre & 18.29 & 10.74 & 15.31 & 21.47 & 34.00 \\
\hline Satellite call centre & 16.19 & 13.36 & 12.15 & 9.11 & 49.19 \\
\hline Head office reservation office & 2.27 & 2.89 & 8.47 & 7.64 & 78.72 \\
\hline Satellite reservation office & 11.25 & 10.21 & 9.38 & 5.63 & 63.54 \\
\hline SANParks website & 34.76 & 10.77 & 15.24 & 12.60 & 26.63 \\
\hline \multicolumn{6}{|l|}{ Activities on website } \\
\hline Find information & 52.14 & 23.35 & 19.26 & 2.14 & 3.11 \\
\hline Read the news releases & 39.88 & 24.79 & 21.07 & 7.85 & 6.40 \\
\hline Check availability & 67.66 & 11.71 & 9.33 & 3.77 & 7.54 \\
\hline
\end{tabular}

Table 4

Reasons for not using the SANParks website to make reservations

\begin{tabular}{|l|c|}
\hline & $\begin{array}{c}\text { Frequency with which } \\
\text { reason was mentioned }\end{array}$ \\
\hline I prefer to use other booking channels & $\mathbf{7 8}$ \\
\hline I don't like paying over the internet & $\mathbf{5 4}$ \\
\hline Pensioners do not receive discount when booking on the SANParks website & $\mathbf{4 5}$ \\
\hline I don't like providing my personal details over the internet & $\mathbf{3 7}$ \\
\hline The SANParks website only allows me to make a booking 10 months in advance, with the \\
other channels I can book 11 months in advance & $\mathbf{3 6}$ \\
\hline I feel that my booking is too complex to be done on the website & $\mathbf{2 8}$ \\
\hline I don't have time to go through the whole booking process online & $\mathbf{2 3}$ \\
\hline I don't want to & $\mathbf{2 2}$ \\
\hline It is not convenient for me & $\mathbf{1 4}$ \\
\hline I find the SANParks website too difficult to use & $\mathbf{1 8}$ \\
\hline The internet connection that I use is too slow & $\mathbf{8}$ \\
\hline I don't know how to access the SANParks website & $\mathbf{7}$ \\
\hline I don't know how to use the internet & $\mathbf{6}$ \\
\hline I don't have internet access & \\
\hline
\end{tabular}

\section{Performance of distribution channels}

A number of variables (unique to each channel) were used to measure the level of satisfaction with the five channels. The mean score of each variable is given in Table 5 below. The level of satisfaction was measured on a 5-point Likert scale, where $1=$ very satisfied and $5=$ very dissatisfied. The composite mean score measuring the overall level of satisfaction with each channel is also provided. From the mean scores, it is evident that the respondents were most satisfied with the satellite reservation office, followed by the satellite call centre, website, head office reservation office and lastly the head office call centre. Given the importance of security when making a travel booking, one of the items measured, which corresponded across all the channels, was the security of the payment process, with the website rated as the lowest of all the channels. This is not surprising, given that some of the most quoted reasons for not using the website were that the respondents did not like paying over the internet and that they did not like having to provide their personal details over the internet (see Table 4). From Table 5 below, it is clear that seven of the items corresponded across all the channels. The composite mean score for these seven items is also provided below. In order to compare the levels of satisfaction across all the channels, the remainder of the results will be based on these seven items. The Cronbach's Alpha values of these seven items guaranteed internal consistency (reliability), with all the channels measuring above 0.85 . 
Table 5

Level of satisfaction across channels

\begin{tabular}{|c|c|c|c|c|c|}
\hline & Website & $\begin{array}{l}\text { Head office } \\
\text { call centre }\end{array}$ & $\begin{array}{l}\text { Satellite call } \\
\text { centre }\end{array}$ & $\begin{array}{l}\text { Head office } \\
\text { reservation } \\
\text { office }\end{array}$ & $\begin{array}{c}\text { Satellite } \\
\text { reservation } \\
\text { office }\end{array}$ \\
\hline Finding the SANParks page & 1.5284 & & & & \\
\hline $\begin{array}{l}\text { Ease of finding the SANParks online } \\
\text { booking facility }\end{array}$ & 1.8521 & & & & \\
\hline Simplicity of process & 1.9377 & 1.9901 & 1.6034 & 1.8723 & 1.4201 \\
\hline Availability of accommodation & 2.2375 & 2.5875 & 2.2170 & 2.5106 & 2.1000 \\
\hline Price of accommodation charged & 2.5665 & 2.6818 & 2.5214 & 2.5761 & 2.3176 \\
\hline Ease of payment process & 1.9749 & 1.9412 & 1.7241 & 1.8043 & 1.5089 \\
\hline Security of payment process & 1.9925 & 1.9767 & 1.7792 & 1.8280 & 1.5789 \\
\hline Time taken to make the reservation & 2.0075 & 2.1201 & 1.6738 & 2.0761 & 1.4793 \\
\hline Recognition of personal details & 2.0677 & & & & \\
\hline $\begin{array}{l}\text { Reputation (credibility of reservation } \\
\text { channel) }\end{array}$ & 1.9359 & 2.0331 & 1.6638 & 1.9140 & 1.5118 \\
\hline Time taken to answer call & & 2.3691 & 1.6301 & & \\
\hline Ease of booking (hassle free) & & 2.0556 & 1.5865 & 1.8925 & 1.4118 \\
\hline Knowledge of reservation staff & & 2.1770 & 1.5837 & 1.9239 & 1.4643 \\
\hline $\begin{array}{l}\text { Personal contact provided by } \\
\text { reservation staff }\end{array}$ & & 2.2295 & 1.5923 & 1.9895 & 1.3787 \\
\hline Overall professionalism & & 2.0820 & 1.6085 & 2.0211 & 1.4142 \\
\hline Waiting time in queue & & & & 2.1778 & 1.4968 \\
\hline Composite mean (all items) & 2.0101 & 2.1870 & 1.7653 & 2.0488 & 1.5902 \\
\hline $\begin{array}{l}\text { Composite mean (corresponding } \\
\text { items) }\end{array}$ & 14.5535 & 15.2371 & 13.2377 & 14.4659 & 11.9222 \\
\hline $\begin{array}{l}\text { Cronbach's alpha (corresponding } \\
\text { items) }\end{array}$ & 0.855 & 0.881 & 0.889 & 0.907 & 0.882 \\
\hline
\end{tabular}

For the remaining results, the composite mean for the corresponding items will be used. This mean across the seven items has a minimum possible value of seven and a maximum value of 35 . Only 9 respondents indicated that they had used all the distribution channels previously, which meant that the satisfaction levels could not be compared across all the channels simultaneously. Paired sample t-tests were used to measure whether significant differences exist between the levels of satisfaction experienced with pairs of channels (in terms of their composite means). The results are given in Table 6, and show that there are significant differences between the level of satisfaction with the website and the head office call centre (the respondents were more satisfied with the website than the call centre); the website and the satellite call centre (the respondents were more satisfied with the satellite call centre than the website); the website and the satellite walk-in reservation office (the respondents were more satisfied with the satellite walk-in reservation office than the website); the head office call centre and the satellite call centre (the respondents were more satisfied with the satellite call centre than the head office call centre); the head office call centre and the satellite walk-in reservation office (the respondents were more satisfied with the satellite walk-in reservation office); and the head office walk-in reservation office and the satellite walk-in reservation office (the respondents were more satisfied with the satellite reservation office). 
Table 6

Paired samples t test statistics

\begin{tabular}{|c|c|c|c|c|c|}
\hline & & Mean & $\mathbf{N}$ & Std. deviation & Sig. (2-tailed) \\
\hline \multirow{2}{*}{ Pair 1} & Website & 14.3220 & 236 & 4.7819 & \multirow{2}{*}{$.000^{* *}$} \\
\hline & Call centre & 15.3051 & 236 & 4.9834 & \\
\hline \multirow{2}{*}{ Pair 2} & Website & 15.7716 & 162 & 4.6429 & \multirow{2}{*}{$.000^{* *}$} \\
\hline & Satellite call centre & 13.3210 & 162 & 4.6847 & \\
\hline \multirow{2}{*}{ Pair 3} & Website & 14.7755 & 49 & 4.7093 & \multirow{2}{*}{.878} \\
\hline & Head office reservation office & 14.6531 & 49 & 5.5548 & \\
\hline \multirow{2}{*}{ Pair 4} & Website & 16.0000 & 101 & 4.4362 & \multirow{2}{*}{$.000^{* *}$} \\
\hline & Satellite reservation office & 12.3564 & 101 & 4.3831 & \\
\hline \multirow{2}{*}{ Pair 5} & Call centre & 15.6968 & 155 & 4.8555 & \multirow{2}{*}{$.000^{* *}$} \\
\hline & Satellite call centre & 13.5097 & 155 & 4.8314 & \\
\hline \multirow{2}{*}{ Pair 6} & Call centre & 14.9500 & 60 & 4.9486 & \multirow{2}{*}{.838} \\
\hline & Head office reservation office & 14.8500 & 60 & 5.3261 & \\
\hline \multirow{2}{*}{ Pair 7} & Call centre & 16.0723 & 83 & 5.0432 & \multirow{2}{*}{$.000^{\star *}$} \\
\hline & Satellite reservation office & 12.6988 & 83 & 4.4578 & \\
\hline \multirow{2}{*}{ Pair 8} & Satellite call centre & 15.1053 & 38 & 5.1925 & \multirow{2}{*}{.158} \\
\hline & Head office reservation office & 16.2895 & 38 & 5.5406 & \\
\hline \multirow{2}{*}{ Pair 9} & Satellite call centre & 12.6303 & 119 & 4.6484 & \multirow{2}{*}{.127} \\
\hline & Satellite reservation office & 12.2437 & 119 & 4.7478 & \\
\hline \multirow{2}{*}{ Pair 10} & Head office reservation office & 15.1429 & 28 & 5.2473 & \multirow{2}{*}{$.029^{*}$} \\
\hline & Satellite reservation office & 13.0714 & 28 & 4.0728 & \\
\hline
\end{tabular}

* The mean difference is significant at the $5 \%$ level, ${ }^{* *}$ significant at the $1 \%$ level

\section{Differences and relationships between variables}

The literature made it clear that the way in which a customer evaluates the distribution channel's performance (or their level of satisfaction with the channel) could differ in terms of culture, gender, age, the frequency of travel, the frequency with which a channel is being used and their level of skill in using the internet. A number of ANOVAs and independent sample t-tests were conducted to see whether the respondents' level of satisfaction with the channels differed. For the sake of brevity, only the significant results are discussed.

Table 7

Gender and level of satisfaction

\begin{tabular}{|c|c|c|c|c|c|}
\hline & $\begin{array}{c}\text { What is your } \\
\text { gender? }\end{array}$ & $\mathbf{N}$ & Mean & $\begin{array}{c}\text { Std. } \\
\text { Deviation }\end{array}$ & $\begin{array}{l}\text { Sig. (2- } \\
\text { tailed) }\end{array}$ \\
\hline \multirow{2}{*}{ Website } & Male & 197 & 14.5482 & 4.8785 & \multirow{2}{*}{.807} \\
\hline & Female & 151 & 14.4172 & 5.0535 & \\
\hline \multirow{2}{*}{ Call centre } & Male & 152 & 15.9868 & 5.1802 & \multirow{2}{*}{$.009^{* *}$} \\
\hline & Female & 124 & 14.4274 & 4.4942 & \\
\hline \multirow{2}{*}{ Satellite call centre } & Male & 116 & 14.0603 & 5.0978 & \multirow{2}{*}{$.006^{* \star}$} \\
\hline & Female & 101 & 12.2673 & 4.2400 & \\
\hline \multirow{2}{*}{ Head office reservation office } & Male & 55 & 15.4000 & 5.2054 & \multirow{2}{*}{$.042^{*}$} \\
\hline & Female & 30 & 13.0333 & 4.7086 & \\
\hline \multirow{2}{*}{ Satellite reservation office } & Male & 92 & 12.8152 & 4.7876 & \multirow{2}{*}{$.003^{* \star}$} \\
\hline & Female & 71 & 10.7746 & 3.6963 & \\
\hline
\end{tabular}

* The mean difference is significant at the $5 \%$ level, ** significant at the $1 \%$ level

First, an independent sample t-test was conducted to establish whether males and females differed in their level of satisfaction with various channels. The results contained in Table 7 show that there are statistically significant differences in the level of satisfaction that males and females 
experience with the call centre, the satellite call centre, the head office reservation office and the satellite reservation office. From the composite mean scores, it appears that females experience higher levels of satisfaction with all the channels named. Next, an ANOVA was conducted to ascertain whether differences existed between a respondent's choice of preferred channel (when making any accommodation booking) and their level of satisfaction with the various SANParks channels. When the ANOVA test could not be used because the group sample sizes were too small, the nonparametric Kruskal-Wallis test (one way analysis of variance by ranks) was used to determine whether statistically significant differences existed. From Table 8, it is evident that there is a statistically significant difference between the choice of a preferred channel and the website, satellite call centre and satellite reservation office. On closer inspection, it can be seen that the respondents were generally more satisfied with the channel that they perceived to be their preferred channel. For example, when a respondent indicated that an establishment's website was their preferred channel when making any accommodation booking, they rated their level of satisfaction with the SANParks website higher than the SANParks' call centre or the reservation office respectively.

Table 8

The difference with regard to the level of satisfaction with a specific channel and between the choice of preferred channel

\begin{tabular}{|c|c|c|c|c|c|}
\hline Satisfaction with & Preferred channel & $\mathbf{n}$ & Mean & Std. deviation & Sig \\
\hline \multirow{3}{*}{ Website } & Website & 164 & 13.2561 & 4.34074 & \multirow{3}{*}{$\begin{array}{c}.000^{* *} \\
(\mathrm{ANOVA})\end{array}$} \\
\hline & Call centre & 63 & 15.9365 & 5.39974 & \\
\hline & Reservation office & 67 & 15.8806 & 4.51772 & \\
\hline \multirow{3}{*}{ Call centre } & Website & 95 & 15.4842 & 4.52620 & \multirow{3}{*}{$\begin{array}{c}0.517 \\
\text { (ANOVA) }\end{array}$} \\
\hline & Call centre & 63 & 14.9206 & 5.35303 & \\
\hline & Reservation office & 69 & 14.6377 & 4.64939 & \\
\hline \multirow{3}{*}{ Satellite call centre } & Website & 46 & 14.5217 & 4.76440 & \multirow{3}{*}{$\begin{array}{c}.001^{* *} \\
\text { (Kruskal- } \\
\text { Wallis) }\end{array}$} \\
\hline & Call centre & 45 & 14.0222 & 4.13680 & \\
\hline & Reservation office & 89 & 11.5955 & 4.75471 & \\
\hline \multirow{3}{*}{ Head office reservation office } & Website & 19 & 15.1053 & 4.17525 & \multirow{3}{*}{$\begin{array}{c}.569 \\
\text { (Kruskal- } \\
\text { Wallis) }\end{array}$} \\
\hline & Call centre & 21 & 13.3810 & 4.99476 & \\
\hline & Reservation office & 28 & 14.2500 & 5.71952 & \\
\hline \multirow{3}{*}{ Satellite reservation office } & Website & 25 & 12.3600 & 3.95685 & \multirow{3}{*}{$\begin{array}{c}.002^{*} \\
\text { (Kruskal- } \\
\text { Wallis) }\end{array}$} \\
\hline & Call Centre & 32 & 13.6875 & 4.44636 & \\
\hline & Reservation office & 76 & 10.6053 & 4.26795 & \\
\hline
\end{tabular}

* The mean difference is significant at the $5 \%$ level, ${ }^{* *}$ significant at the $1 \%$ level

An independent sample t-test was carried out to determine whether a difference existed between a respondent's level of skill in using the internet and their level of satisfaction with the various SANParks channels. As expected, the only item that showed a statistically significant difference was the fact that the respondents who regarded themselves as having a high level of skill in using the internet $(M=14.2853)$, rated their level of satisfaction with the SANParks website significantly higher $(\mathrm{P}<.001)$ than did those who regarded themselves as having a low level of skill $(\mathrm{M}=17.7826)$.

A series of ANOVAs was also conducted to see whether differences existed between the frequency with which a channel was being used to make a SANParks booking and the respondent's level of satisfaction with that specific channel. Table 3 shows the frequency with which specific channels are used to make SANParks bookings. Table 9 indicates the results of the ANOVAs. The results consistently show that the respondents who use a specific channel more frequently are also those who tend to be the most satisfied with that specific channel. For example, when looking at the frequency with which the website is being used and the customers' level of satisfaction with the website, results show that there is a significant difference between the 
customers who answered "always", "sometimes", "rarely" and "never", as well as between the customers who answered "most of the time", "sometimes", "rarely" and "never". The mean scores for these groups furthermore indicate that the group who always used the SANParks website was also the most satisfied with the website.

Table 9

Frequency of use and level of satisfaction

\begin{tabular}{|c|c|c|c|c|c|}
\hline Satisfaction with & Frequency of use & $\mathbf{N}$ & Mean $^{* * *}$ & Std. deviation & Sig \\
\hline Website & $\begin{array}{l}\text { Always } \\
\text { Most of the time } \\
\text { Sometimes } \\
\text { Rarely } \\
\text { Never } \\
\text { Total }\end{array}$ & $\begin{array}{r}161 \\
45 \\
69 \\
55 \\
40 \\
370\end{array}$ & $\begin{array}{l}12.6957^{\mathrm{a}} \\
12.8889^{\mathrm{b}} \\
15.7681^{\mathrm{ab}} \\
17.3091^{\mathrm{ab}} \\
18.1500^{\mathrm{ab}} \\
14.5676\end{array}$ & $\begin{array}{l}4.4596 \\
4.3234 \\
4.5379 \\
3.5375 \\
5.3376 \\
4.9136\end{array}$ & $.000^{* *}$ \\
\hline Call centre & $\begin{array}{l}\text { Always } \\
\text { Most of the time } \\
\text { Sometimes } \\
\text { Rarely } \\
\text { Total }\end{array}$ & $\begin{array}{r}82 \\
51 \\
67 \\
88 \\
288\end{array}$ & $\begin{array}{l}13.6463^{\mathrm{a}} \\
14.4118^{\mathrm{b}} \\
14.7612^{\mathrm{c}} \\
17.3295^{\mathrm{abc}} \\
15.1667\end{array}$ & $\begin{array}{l}4.9024 \\
4.5964 \\
5.2022 \\
4.2823 \\
4.9478\end{array}$ & $.000^{* *}$ \\
\hline Satellite call centre & $\begin{array}{l}\text { Always } \\
\text { Most of the time } \\
\text { Sometimes } \\
\text { Rarely } \\
\text { Total }\end{array}$ & $\begin{array}{r}69 \\
63 \\
55 \\
32 \\
219\end{array}$ & $\begin{array}{l}11.0725^{\mathrm{a}} \\
12.5397^{\mathrm{b}} \\
15.1455^{\mathrm{ab}} \\
16.4375^{\mathrm{ab}} \\
13.3014\end{array}$ & $\begin{array}{l}4.3057 \\
4.0593 \\
4.7118 \\
4.4789 \\
4.7815\end{array}$ & $.000^{* *}$ \\
\hline Head office reservation office & $\begin{array}{l}\text { Always } \\
\text { Most of the time } \\
\text { Sometimes } \\
\text { Rarely } \\
\text { Total }\end{array}$ & $\begin{array}{l}11 \\
12 \\
35 \\
28 \\
86\end{array}$ & $\begin{array}{l}11.0909^{a} \\
15.2500 \\
13.4000 \\
16.8571^{a} \\
14.4884\end{array}$ & $\begin{array}{l}4.3693 \\
4.3511 \\
4.8154 \\
5.2685 \\
5.1672\end{array}$ & $\begin{array}{c}.009^{\star *} \\
\text { (Kruskal Wallis) }\end{array}$ \\
\hline Satellite reservation office & $\begin{array}{l}\text { Always } \\
\text { Most of the time } \\
\text { Sometimes } \\
\text { Rarely } \\
\text { Total }\end{array}$ & $\begin{array}{r}51 \\
49 \\
40 \\
23 \\
165\end{array}$ & $\begin{array}{l}10.1176^{\mathrm{a}} \\
11.6939 \\
13.1000^{\mathrm{a}} \\
14.1739^{\mathrm{a}} \\
11.8909\end{array}$ & $\begin{array}{l}4.1408 \\
3.8687 \\
4.0686 \\
4.8678 \\
4.3645\end{array}$ & $.001^{* *}$ \\
\hline
\end{tabular}

* The mean difference is significant at the 0.05 level

** The mean difference is significant at the $1 \%$ level

*** Superscripts with the same letters indicate a significant difference between means at the 0.05 level

Lastly, Pearson chi-squared tests of independence were used to test the relationship between the frequency with which various channels are used to make SANParks bookings and a respondent's choice of preferred channel when making any accommodation booking (see Table 10). The Pearson chi-squared test is a non-parametric test that is applicable in situations in which the researcher wants to examine the relationship or association between two nominal variables (Cooper \& Schindler, 2008). When the Pearson chi-square values could not be used because more than $20 \%$ of the cells had expected counts of less than 5 , the value of Cramer's V (a measure of the strength of association between nominal variables) and its associated significance was used to determine whether there were statistically significant relationships (Cooper \& Schindler, 2008). It is interesting to note that, when the respondents indicated that they used the SANParks satellite call centre "always/most of the time" to make a booking with SANParks, they were more likely to choose an establishment's call centre or reservation office as their most preferred option when making any accommodation booking $(\mathrm{P}<.000)$. This was also true of the SANParks call centre $(\mathrm{P}<.000)$ and the satellite reservation office $(\mathrm{P}<.000)$. In addition, when the respondents specified that they used the SANParks website "always/most of the time" to book with SANParks, they were more likely to prefer an establishment's website when they made any accommodation booking $(\mathrm{P}<.000)$. This could mean that visitors tended to use a specific distribution channel for all their accommodation bookings, regardless of the supplier. In other words, if the visitor used a more traditional channel for their SANParks booking, they would also prefer to use this channel for any other accommodation booking. 
Table 10

Frequency of use and preferred channel when making ANY accommodation booking

\begin{tabular}{|c|c|c|c|c|c|c|}
\hline \multirow[b]{2}{*}{ Channel } & \multirow[b]{2}{*}{ Frequency } & \multicolumn{3}{|c|}{$\begin{array}{c}\text { Preferred channel when making ANY accommodation } \\
\text { booking }\end{array}$} & \multirow[b]{2}{*}{ Total } & \multirow{2}{*}{$\begin{array}{l}\text { Chi } \\
\text { Square/Cra } \\
\text { mer's V }\end{array}$} \\
\hline & & $\begin{array}{l}\text { The establish- } \\
\text { ment's website }\end{array}$ & $\begin{array}{l}\text { The establish- } \\
\text { ment's call } \\
\text { centre }\end{array}$ & $\begin{array}{l}\text { The establish- } \\
\text { ment's reservation } \\
\text { office }\end{array}$ & & \\
\hline \multirow{5}{*}{$\begin{array}{l}\text { Satellite call } \\
\text { centre }\end{array}$} & Always & 6 & 12 & 48 & 66 & \multirow{5}{*}{$\mathrm{P}<.000$} \\
\hline & Most of the time & 6 & 18 & 30 & 54 & \\
\hline & Sometimes & 21 & 12 & 10 & 43 & \\
\hline & Rarely & 16 & 6 & 10 & 32 & \\
\hline & Total & 49 & 48 & 98 & 195 & \\
\hline \multirow{5}{*}{ Call centre } & Always & 6 & 29 & 31 & 66 & \multirow{5}{*}{$P<.000$} \\
\hline & Most of the time & 13 & 21 & 11 & 45 & \\
\hline & Sometimes & 39 & 7 & 13 & 59 & \\
\hline & Rarely & 49 & 10 & 21 & 80 & \\
\hline & Total & 107 & 67 & 76 & 250 & \\
\hline \multirow{5}{*}{$\begin{array}{l}\text { Satellite } \\
\text { reservation } \\
\text { office }\end{array}$} & Always & 2 & 9 & 33 & 44 & \multirow{5}{*}{$P<.000$} \\
\hline & Most of the time & 4 & 10 & 28 & 42 & \\
\hline & Sometimes & 11 & 7 & 9 & 27 & \\
\hline & Rarely & 8 & 8 & 7 & 23 & \\
\hline & Total & 23 & 25 & 44 & 92 & \\
\hline \multirow{5}{*}{ Website } & Always & 112 & 14 & 12 & 138 & \multirow{5}{*}{$\mathrm{P}<.000$} \\
\hline & Most of the time & 30 & 5 & 5 & 40 & \\
\hline & Sometimes & 19 & 15 & 19 & 53 & \\
\hline & Rarely & 7 & 16 & 25 & 48 & \\
\hline & Total & 168 & 50 & 61 & 279 & \\
\hline
\end{tabular}

\section{Discussion}

Even though tourism literature has acknowledged the significance of distribution, research in this area has, for the most part, been approached from the supply side, with very little attention given to the customer's requirements. Connolly and Olsen (2001) argue that the performance by hotels and their competitiveness is meaningfully reliant on their capability of meeting the customers' requirements in an efficient and effective manner.

Interestingly, the results showed that looking still does not necessarily result in booking, with almost twice as many respondents agreeing that they used the website to check the availability of accommodation than those agreeing that they had previously made a booking on the website. The most frequently-quoted reasons for not booking online were that the respondents preferred to use other booking channels; they did not like paying over the internet and the fact that pensioners did not receive a discount when booking on the SANParks website. It was further revealed that, even though the website was the most frequently used, it was not necessarily the channel with which the respondents were the most satisfied. This is contrary to what Lubbe (2007) said, when she pointed out that the effectiveness of a website in gratifying the consumers' needs may influence its use. This raises the question of whether a supplier should develop their distribution strategy according to the most used channels, or the channels with which the customers are most satisfied. It was interesting to note that the respondents were consistently more satisfied when using intermediaries to facilitate their bookings. This is in line with Pearce and Tan's (2006) argument that indirect channels often offer a better service simply because of their specialisation and scale of operation. As they are specialised, Pearce and Tan (2006) feel that it may be more advantageous to use intermediaries, .in addition to the fact that these might appeal more to the customers' 
requirements. Satisfying the needs and wants of suppliers and customers should be the main motivation for intermediaries (Pearce \& Tan, 2006).

When asked about the security of the payment process, the respondents rated the website the lowest of all the channels. Respondents who do not use the website for bookings mentioned the following as reasons: "I don't like paying over the internet" and "I don't like providing my personal details over the internet". Buhalis and Law (2008) suggest that business organisations should put greater emphasis on guarding themselves and their customers against the damages related to online crimes. They mentioned that, if customers had privacy concerns, this could lead to a situation where they used the internet to look for information, but would still buy offline. Kolsaker, Lee-Kelley and Choy (2004) said that privacy concerns have a significant influence and inhibit buying online travel products. This might also be the case with SANParks, whereby the respondents indicated that they looked for information online, but preferred other channels for booking. Chen (2006) and Bauernfiend and Zins (2006) encourage website owners to make sure that customers feel comfortable and safe when conducting online bookings.

The results further showed significant differences between variables. Males and females differ in their levels of satisfaction, with females consistently showing higher levels of satisfaction across all channels than did males. On the contrary, Lubbe (2007) found no significant difference between males and females in their satisfaction rating of the appearance, perceived value and quality of information on an airline's website. The results also showed a significant difference between a customer's preferred channel when making any accommodation booking, and their level of satisfaction with SANParks' channels. Not surprisingly, the results indicated significant differences between a respondent's level of skill in using the internet and their level of satisfaction with the SANParks channels as well as between the frequency with which a channel is used to make a SANParks booking and the respondent's level of satisfaction with that specific channel. This confirms Lubbe's (2007) finding that those respondents who mostly used a specific distribution channel are more satisfied with that specific channel than those respondents who sometimes or never use the channel.

Like all studies, this paper is not without limitations. Perhaps the greatest limitation relates to the use of a non-probability sampling method. This means that the results of this study apply only to the selected respondents, and cannot be generalised to the broader population. Despite these limitations, this paper makes a significant contribution to the limited research available on the importance of the distribution function of tourism suppliers from the customer's viewpoint. What is more, it adds to the almost non-existent literature available on the topic of tourism distribution channels in South Africa, national parks and, more specifically, SANParks. It also provides knowledge on the South African customer and their tourism distribution requirements. It shows that, even though tourism suppliers believe that electronic channels are the future, SANParks' customers still value the personal touch provided by traditional channels, and are more satisfied with certain traditional channels than with the electronic channels. Even though no significant relationship was shown between the age of the respondent and their distribution channel preference, it is necessary for suppliers like SANParks to consider the demographic profile of their customer when deciding which distribution channels to use. Furthermore, suppliers like SANParks, should pay attention to the distribution requirements of their customers, and make sure that the channels they promote satisfy these requirements. They should ensure that their electronic distribution channels are developed in such a way that they still present some form of personal contact and personalisation to customers.

\section{Conclusion}

While the majority of research studies in the context of tourism distribution channels have shown the importance and popularity of electronic distribution channels amongst customers, this paper both cautions suppliers like SANParks not to assume that they know their customers' distribution channel requirements and urges them to rethink their distribution strategies and become more 
customer-focused in their approach to distribution. According to Elliot and Joppe (2009), even though Information and Communication Technologies (ICTs) (including supplier websites) have become a crucial tool for the current tourism industry, they have not replaced the human element in the industry. This study has shown that human contact is still very important to some respondents when they make accommodation bookings, and acts as a reminder that they might choose a channel based on the level of human contact that the channel provides.

Even though a number of studies on the selection and performance of distribution channels have been conducted from the suppliers' viewpoint (Inversini \& Masiero, 2014) the contribution of this paper lies in the fact that the demand side was investigated and consumers were asked about their selection and performance rating of distribution channels when making a booking with SANParks.

Future research could focus on other tourism suppliers in the South African context to see whether the distribution requirements of SANParks' customers differ from those of the customers of other tourism suppliers.

\section{References}

AKHTER, S.H. 2003. Digital divide and purchase intention: Why demographic psychology matters. Journal of Economic Psychology, 24:321-327.

ALAMDARI, F. \& MASON, K. 2006. The future of airline distribution. Journal of Transport Management, 12:122-34.

ALCÁZAR MARTÍNEZ, B. 2002. Los canales de distribución en el sector turístico. Madrid: ESIC Editorial. ANDERSON, E., DAY, G.S. \& RANGAN, V.K. 1997. Strategic channel design. Sloan Management Review, 38(4):59-69.

BAI, B., LAW, R. \& WEN, I. 2008. The impact of website quality on customer satisfaction and purchase intentions: Evidence from Chinese online visitors. International Journal of Hospitality Management, 27: 391-402.

BAUERNFEIND, U. \& ZINS, A. 2006. The perception of exploratory browsing and trust with recommender websites. Information Technology \& Tourism, 8 (2):121-136.

BELDONA, S., RACHERLA, P. \& MUNDHRA, G. 2011. To buy or not to buy: Indian consumers' choice of online versus offline channels for air travel purchase. Journal of Hospitality Marketing \& Management, 20(8):831-854.

BENNETT, M.M. \& LAI, C.W.K. 2005. The impact of the internet on travel agencies in Taiwan. Tourism and Hospitality Research, 6(1):8-23.

BUCKLEY, P.J. 1987. Tourism: An economic transactions analysis. Tourism Management, 8(3):190-94.

BUHALIS, D. 2000. Distribution channels in the changing travel industry. International Journal of Tourism Research, 2(2):137-139.

BUHALIS, D. 2001. Tourism distribution channels: Practices and processes. Published in D. Buhalis \& E. Laws (eds.) Tourism distribution channels: Practices, issues and transformations. London: Continuum.

BUHALIS, D. \& LAW, R. 2008. Progress in tourism management: Twenty years on and 10 years after the internet: The state of eTourism research, Tourism Management, 29(4):609-623.

BUHALIS, D. \& LICATA, M.C. 2002. The future eTourism intermediaries. Tourism Management, 23 : 207-220.

BURGERS, A., RUYTER, K., KEEN, C. \& STREUKENS, S. 2000. Customer expectation dimensions of voice-to-voice service encounters: A scale development study. International Journal of Service Industry Management, 11(2):142-61.

CHEN, C. 2006. Identifying significant factors influencing consumer trust in an online travel site. Information Technology \& Tourism, 8(2):197-214.

CHEYNE, J., DOWNES, M. \& LEGG, S. 2006. Travel agent vs. internet: What influences travel consumer choices? Journal of Vacation Marketing, 12(1):41-57.

COELHO, F. \& EASINGWOOD, C. 2008. A model of the antecedents of multiple channel usage. Journal of Retailing and Consumer Services, 15(1):32-41. 
CONNOLLY, D.J. \& OLSEN, M.D. 2001. An environmental assessment of how technology is reshaping the hospitality industry. Tourism and Hospitality Research, 3(1):73-93.

COOPER, D.R. \& SCHINDLER, P.S. 2008. Business research methods (10 ${ }^{\text {th }}$ ed.) Singapore: McGraw Hill. CRNOJEVAC, I.H., GUGIĆ. J. \& KARLOVČAN, S. 2010. eTourism: A comparison of online and offline bookings and the importance of hotel attributes. Journal of Information and Organizational Sciences, 34(1):41-54.

CROTTS, J.C., AZIZ, A. \& RASCHID, A. 1998. Antecedents of suppliers' commitment to wholesale buyers in the international travel trade. Tourism Management, 19(2):127-134.

DEAN, A.M. 2004. Rethinking customer expectations of service quality: Are call centers different? Journal of Services Marketing, 18(1):60-77.

DE JAGER, K. 2014. Choosing between travel agencies and the internet. Unpublished Master's dissertation. University of Johannesburg.

DOLNICAR, S. \& LAESSER, C. 2007. Travel agency marketing strategy: Insights from Switzerland. Journal of Travel Research, 46(2):133-46.

ELLIOT, S. \& JOPPE, M. 2009. A case study and analysis of e-tourism curriculum development. Journal of Teaching in Travel \& Tourism, 9(3-4):230-247.

GARCÍA-FALCÓN, J.M. \& MEDINA-MUÑOZ, D. 1999. The relationship between hotel companies and travel agencies: An empirical assessment of the United States market. The Service Industries Journal, 19(4): $102-122$.

GIAGLIS, G.M., KLEIN, S. \& O'KEEFE, R.M. 2002. The role of intermediaries in electronic marketplaces: Developing a contingency model. Information Systems Journal, 12(3):231-246.

GOLMOHAMMADI, A.R., JAHANDIDEH, B. \& O'GORMAN, K.D. 2012. Booking on-line or not: A decision rule approach. Tourism Management Perspectives, 2-3:85-88.

GREEN, C.E. 2005. De-mystifying distribution: Building a distribution strategy one channel at a time. HSMAI Foundation.

HUANG, L., CHEN, K. \& WU, Y. 2009. What kind of marketing distribution mix can maximize revenues: The wholesaler travel agencies' perspective? Tourism Management, 30:733-739

INVERSINI, A. \& MASIERO, L. 2014. Selling rooms online: The use of social media and online travel agents. International Journal of Contemporary Hospitality Management, 26(2):272-292.

IZQUIERDO-YUSTA, A. \& MARTI'NEZ-RUIZ, M.P. 2011. Assessing the consumer's choice of purchase channel in the tourism sector: Evidence from Spain. EuroMed Journal of Business, 6(1):77-99.

JAISWAL, A.K. 2008. Customer satisfaction and service quality measurement in Indian call centres. Managing Service Quality, 18 (4):405-416.

JUN, S.H., VOGT, C.A. \& MACKAY, K.J. 2010. Online information search strategies: A focus on flights and accommodations. Journal of Travel \& Tourism Marketing, 27(6):579-595.

KAEWKITIPONG, L. 2010. Disintermediation in the tourism industry: Theory vs practice. Published in Nelson, M.L. (ed.) Sustainable e-business management, Springer, Berlin:160-171.

KEININGHAM, T.L., AKSOY, L., ANDREASSEN, T.W., COOIL, B. \& WAHREN, B.J. 2006. Call center satisfaction and customer retention in a co-branded service context. Managing Service Quality, 16(3):269-89. KIM, M., CHUNG, N. \& LEE, C. 2011. The effect of perceived trust on electronic commerce: Shopping online for tourism products and services in South Korea. Tourism Management, 32:256-265.

KIM, W.G. \& KIM, D.J. 2004. Factors affecting online hotel reservation intention between online and nononline customers. Hospitality Management, 23:381-395.

KIM, W.G. \& LEE, H.Y. 2004. Comparison of web service quality between online travel agencies and online travel supplies. Journal of Travel and Tourism Marketing, 17(2/3):105-116.

KIM, D.Y., LEHTO, X.Y. \& MORRISON, A.M. 2007. Gender differences in online travel information search: Implications for marketing communications on the internet. Tourism Management, 28(2):423-433.

KOLSAKER, A., LEE-KELLEY, L. \& CHOY, P.C. 2004. The reluctant Hong Kong consumer: Purchasing travel online. International Journal of Consumer Studies, 28(3):295-304.

KONTIS, A. \& LAGOS, D. 2015. Factor framework for the evaluation of multichannel marketing mixes in 5* city hotels. International Conference on Strategic Innovative Marketing, IC-SIM 2014, September 1-4, 2014, Madrid, Spain. Procedia - Social and Behavioral Sciences, 175:408-414. 
KOTLER, P., BOWEN, J. \& MAKENS, J. 1996. Marketing and hospitality for tourism. Upper Saddle River, NJ: Prentice Hall.

LAW, R. 2009. Disintermediation of hotel reservations: The perception of different groups of online buyers in Hong Kong. International Journal of Contemporary Hospitality Management, 21(6):766-772.

LAW, R. \& HSU, C.H.C. 2006. Importance of hotel website dimensions and attributes: Perceptions of online browsers and online purchasers. Journal of Hospitality \& Tourism Research, 30(3):295-312.

LAW, R., LEUNG, K. \& WONG, J. 2004. The impact of the internet on travel agencies. International Journal of Contemporary Hospitality Management, 16(2):100-107.

LAW, R., LEUNG, R., LO, A., LEUNG, D., HOC, L. \& FONG, N. 2015. Distribution channel in hospitality and tourism. International Journal of Contemporary Hospitality Management, 27 (3):431-452.

LITUCHY, T.R. \& RAIL, A. 2000. Bed and breakfasts, small inns, and the internet: The impact of technology on the globalisation of small businesses. Journal of International Marketing, 8(2):86-97.

LUBBE, B. 2005. A new revenue model for travel intermediaries in South Africa: The negotiated approach. Journal of Retailing and Consumer Services, 12:385-396.

LUBBE, B. 2007. The effect of Internet apprehension and website satisfaction on air travellers' adoption of an airline's website. Journal of Air Transport Management, 13:75-80.

LU, Q., YANG, Y. \& YUKSEL, U. 2015. The impact of a new online channel: An empirical study. Annals of Tourism Research, 54:136-155.

MICHOPOULOU, E. \& BUHALIS, D. 2008. Performance measures of net-enabled hypercompetitive industries: The case of tourism. International Journal of Information Management, 28:168-180.

MIDDLETON, V. \& CLARKE, J. 2001. Marketing in travel and tourism ( $3^{\text {rd }}$ ed.) Oxford: ButterworthHeinneman.

MUSANTE, M.D., BOJANIC, D.C. \& ZHANG, J. 2009. An evaluation of hotel website attribute utilization and effectiveness by hotel class. Journal of Vacation Marketing, 15:203.

MOROSANA, C. \& JEONG, M. 2008. Users' perceptions of two types of hotel reservation Web sites. International Journal of Hospitality Management, 27:284-292.

MORRISON, A. 1989. Hospitality and tourism marketing. Albany: Delmar.

NOVAK, J. \& SCHWABE, G. 2009. Designing for reintermediation in the brick-and-mortar world: Towards the travel agency of the future. Electron Markets, 19:15-29.

O'CONNOR, P. 1999. Electronic Information Distribution in Tourism and Hospitality. Wallingford, CT: CABI.

ÖÖRNI, A. 2003. Consumer search in electronic markets: An experimental analysis of travel services. European Journal of Information Systems, 12:30-40.

PALMER, A. \& MCCOLE, P. 1999. The virtual re-intermediation of travel services: A conceptual framework and empirical investigation. Journal of Vacation Marketing, 6(1):33-47.

PAN, B., MACLAURIN, T. \& CROTTS, J.C. 2007. Travel blog and the implications for destination marketing. Journal of Travel Research, 46(1):35-45.

PAVLOU, P.A. 2003. Consumer acceptance of electronic commerce: Integrating trust and risk with the technology acceptance model. International Journal of Electronic Commerce, 7(3):69-103.

PEARCE, D G. 2002. New Zealand holiday travel to Samoa: a distribution channels approach. Journal of Travel Research, 41(2):197-205.

PEARCE, D.G. 2008. A needs-functions model of tourism distribution. Annals of Tourism Research, 35(1): 148-168.

PEARCE, D.G. 2009. Channel design for effective tourism distribution strategies. Journal of Travel \& Tourism Marketing, 26(5-6):507-521.

PEARCE, D.G. \& SCHOTT, C. 2005. Tourism distribution channels: The visitors' perspective. Journal of Travel Research, 44:50-63.

PEARCE, D. \& TAN, R. 2006. The distribution mix for tourism attractions in Rotorua, New Zealand. Journal of Travel Research, 44:250-258.

PEARCE, D.G., TAN, R. \& SCHOTT, C. 2007. Distribution channels in international markets: A comparative analysis of the distribution of New Zealand tourism in Australia, Great Britain and the USA. Current Issues in Tourism, 10(1):33-60. 
PEARCE, D. G. \& TANIGUCHI, M. 2008. Channel performance in multi-channel tourism distribution systems. Journal of Travel Research, 46(3):256-267.

PHELAN, K.V., CHRISTODOULIDOU, N., COUNTRYMAN, C.C. \& KISTNER, L.J. 2011. To book or not to book: The role of hotel web site heuristics. Journal of Services Marketing, 25(2):134-148.

POWELL, M. \& ANSIC, D. 1997. Gender differences in risk behavior in financial decision-making: An experimental analysis. Journal of Economic Psychology, 18:605-628.

RYAN, C. \& CLIFF, A. 1997. Do travel agencies measure up to customer expectation? An empirical investigation of travel agencies' service quality as measured by SERVQUAL. Journal of Travel \& Tourism Marketing, 6(2):1-31.

SAAYMAN, M. \& SAAYMAN, A. 2008. Why travel motivation and socio-demographics matter in managing a national park. Koedoe-African Protected Area Conservation and Science, 51(1):1-9.

SABIOTE, C.M., FRÍAS, D.M. \& CASTAÑEDA, J.A. 2012. Culture as a moderator of the relationship between service quality and the tourist's satisfaction with different distribution channels. Journal of Travel \& Tourism Marketing, 29(8):760-778.

SANCHEZ, J.F. \& AHMET, S. 2005. Hotel yield management using different reservation modes. International Journal of Contemporary Hospitality Management, 17(2):136-146.

SANParks. 2013. About us. Available at: http://www.sanparks.co.za/about/ [accessed June 2013].

SCHOLTZ, M., DU PLESSIS, L. \& SAAYMAN, M. 2014. Understanding visitors to Kruger National Park. Not known. Potchefstroom.

SCHOTT, C. 2007. Selling adventure tourism: A distribution channels perspective. International Journal of Tourism Research, 9:257-274.

SEN, R. \& KING, R.C. 2003. Revisit the debate on intermediation, disintermediation and reintermediation due to e-commerce. Electronic Markets, 13(2):153-162.

SHARPLEY, R. \& PEARCE, T. 2007. Tourism, marketing and sustainable development in the English national parks: The role of national park authorities. Journal of Sustainable Tourism, 15(5):557-573.

STARKOV, M. \& SAFER, M.M. 2010. Hoteliers' 2010 top ten internet marketing resolutions. hospitality eBusiness strategies (HeBS). Available at: http://www.hospitalityebusiness.com/ articles.php [accessed February 2010].

STERN, L.W. \& EL-ANSARY, A.I. 1992. Marketing channels $\left(4^{\text {th }}\right.$ ed.) Englewood Cliffs, NJ: Prentice-Hall. SUÁREZ ÁLVAREZ, L., DÍAZ MARTÍN, A.M., \& CASIELLES, R.V. 2007. Relationship marketing and information and communication technologies: Analysis of retail travel agencies. Journal of Travel Research, 45(4):453-463.

THAKRAN, K. \& VERMA, R. 2013. The emergence of hybrid online, distribution channels in travel, tourism and hospitality. Cornell Hospitality Quarterly, 54(3):240-247.

TSAI, W., CHOU, W. \& LAI, C. 2010. An effective evaluation model and improvement analysis for national park websites: A case study of Taiwan. Tourism Management, 31:936-952.

TSAI, H.T., HUANG, L. \& LIN, C.G. 2005. Emerging e-commerce development model for Taiwanese travel agencies. Tourism Management, 26(5):787-796.

WALLE, A. 1996. Tourism and Internet: opportunities for direct marketing. Journal of Travel Research, 35(1):72-77.

WEBER, K. \& ROEHL, W.S. 1999. Profiling people searching for and purchasing travel products on the World Wide Web. Journal of Travel Research, 37:291-298.

WOLFE, K.C., HSU, H.C. \& KANG, S.K. 2004. Buyer characteristics among users of various travel intermediaries. Journal of Travel and Tourism Marketing, 17(2/3):51-62.

YILMAZ, Y. \& BITITCI, U. 2006. Performance measurement in tourism: A value chain model. International Journal of Contemporary Hospitality Management, 18(4):341-349. 